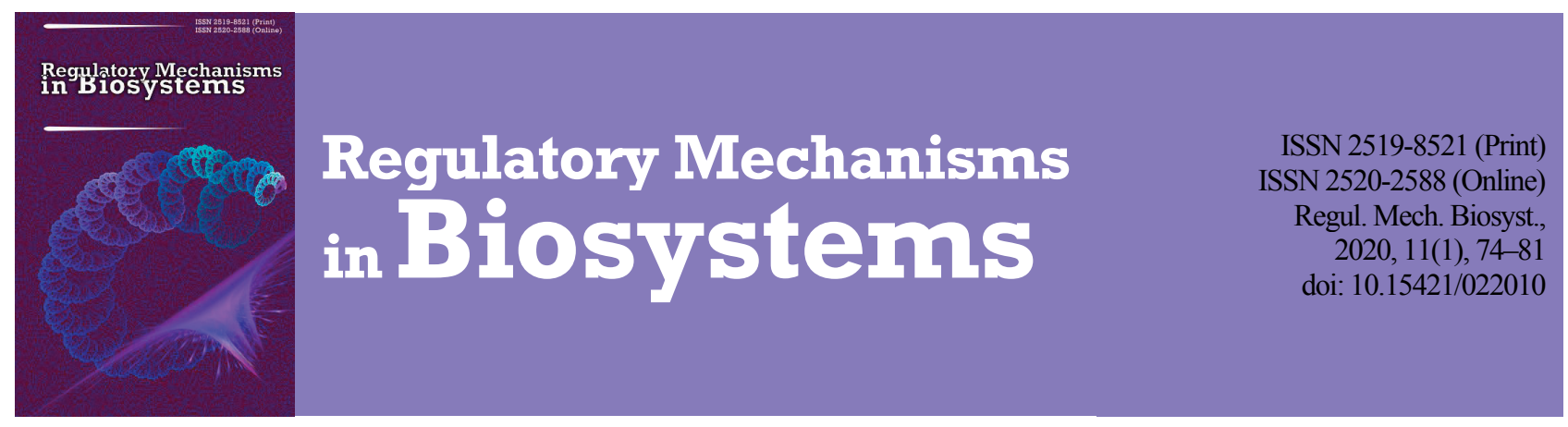

\title{
Epidemiology and features of the measles course in children during the outbreak of 2018-2019 in the city of Mariupol
}

\author{
A. A. Koniushevska*, T. A. Parkhomenko*, M. V. Sharunova**, A. B. Kazantsev**, D. V. Yakovenko* \\ *Donetsk National Medical University, Liman, Ukraine \\ **I. K. Matsuk City Hospital No. 4, Mariupol, Ukraine
}

Article info

Received 02.02.2020

Received in revised form 28.02.2020

Accepted 01.03.2020

Donetsk National Medical University, Pryvokzalna st. 27, Lyman, 844 04, Ukraine Tel.: + 38-096-566-43-85.

E-mail: konyshevskaya63@ gmail.com

I. K. Matsuk City Hospital No. 4, Pashkovsky st., 4,

Mariupol, 87502, Ukraine.

Tel.: + 38-067-37-6-21-89.

E-mail:

m.sharunova@gmail.com

Koniushevska, A. A., Parkhomenko, T. A., Sharunova, M. V., Kazantsev, A. B., \& Yakovenko, D. V. (2020). Epidemiology and features of the measles course in children during the outbreak of 2018-2019 in the city of Mariupol. Regulatory Mechanisms in Biosystems, 11(1), 74-81. doi:10.15421/022010

In 2017, Ukraine ranked in the top three among European countries in terms of measles incidence, and ranked first in measles growth in 2018. High morbidity, mortality and development of complications make the problem of knowing features of the measles clinical course, timely diagnosis and active prevention highly relevant. The purpose of the research is to study the dynamics of the incidence and clinical features of measles in children during the outbreak of 2018-2019 in the city of Mariupol, Donetsk region. A peculiarity of the measles outbreak in 2018-2019 in Mariupol is prevalence of the disease in preschool children (60.4\%), including $30.2 \%$ - those under one year of age; low vaccination rate: $52.3 \%$ of children unvaccinated; only $22.2 \%$ of children were vaccinated twice, according to the schedule. In all age groups, a moderately severe measles course prevailed (69.8\%). The clinical course of measles in preschool and school age children had definitive features. Thus, Belsky-Filatov-Koplik spots were observed three times more frequently in preschool children than in schoolchildren (63.9\% and $23.3 \%$, respectively). Abdominal pain and diarrhea were only observed in children under 6 years of age (30.2\%). Skin pigmentation was absent in children under one year of age and was detected in preschool and school-age children (69.8\%). Skin sloughing was only observed in schoolchildren (10.4\%). Severe disease course occurred in patients of all ages (29.3\%), but children aged under one year and preschool children with severe disease were two times more numerous than those of the school age. Among the observed complications, the vast majority were associated with the respiratory organs: pneumonia (38.3\%), subcutaneous emphysema (1.7\%), bronchitis (53.2\%), laryngitis (3.3\%), otitis media (5\%). No fatalities were observed. The city should form a commitment to immunization, restore public trust in vaccination, using all forms and means of information, and develop a program to implement the vaccination schedule into practice.

Keywords: infection; children; measles; clinical picture; differences.

\section{Introduction}

In Ukraine, such infectious diseases as measles related to VPDs (vaccine-preventable diseases) do not lose their relevance today because the outbreaks of the infection that began in June 2017 are still far from abating (Orenstein et al., 2018; Trykhlib et al., 2018; Utenkova, 2018).

Measles has been known to mankind since ancient times and justified the name "baby plague" because it was characterized by high morbidity and high mortality rates (Timchenko et al., 2017; Zhanga et al., 2017; Portnoy et al., 2018). Prior to the introduction of the measles vaccination, globally about 130 million people suffered from this were disease annually, more than 2.5 million of them died (Artemova \& Kulichenko, 2017; Marusik, 2017; Yunasova et al., 2019). The second period in the evolution of measles treatment is associated with the use of antibiotics, which has led to a reduction in complications and a significant reduction in mortality. The third stage was characterized by implementation of mass immunization, which was introduced in our country in 1968, and led to a sharp decrease in the incidence of measles within the infant population. Since the 1970 s measles has been characterized by a cyclic epidemic process with outbreaks every 5-6 years (Pozdnyakov \& Chernyavskaya, 2018; Smyrnova et al., 2019), which is caused by the accumulation of susceptible non-immune individuals.

Due to the WHO's campaign of measles vaccination performed during $2000-2015$, measles mortality rates have decreased by $79 \%$ in the world (Doshi et al., 2017; Yunasova et al., 2019). At the same time, in 2010, there were 139,300 deaths from measles worldwide, in 2014 mortality was not so high - slightly less than 115,000 cases, but it made almost 380 cases per day, or 15 cases per hour (Verguet et al., 2015; Timchenko et al., 2017; Portnoy et al., 2018). In 2016, 89,780 deaths were reported - the number of deaths from this disease had first fallen globally below 100,000 cases per a year (Ishchuk \& Stetsyuk, 2018). Major measles outbreaks have been observed in developing countries, including those in Southeast Asia (Pham et al., 2014), the Democratic Republic of the Congo, Ethiopia, India, Nigeria, Pakistan (Ishchuk \& Stetsyuk, 2018; Muscat et al., 2018; Nandi et al., 2019). In 2013-2015, another measles epidemic spread, involving almost all countries in the Western Pacific: China, Japan, Mongolia, Republic of Korea, Philippines, Vietnam, Papua New Guinea and others (Antipova et al., 2018).

In September 2016, the WHO declared the region of America free of measles as a result of a 22-year vaccination campaign (Orenstein et al., 2018; Ishchuk \& Stetsyuk, 2018; Molochkova et al., 2019). Denmark, Spain and the United Kingdom have completely eliminated measles (Ishchuk \& Stetsyuk, 2018). Measles elimination means the absence of endemic measles virus circulation in the region for 12 months, with a well-functioning epidemiological surveillance system (Bester, 2016; Gastanaduy et al., 2018). However, in 2017 the number of measles cases grew dramatically again worldwide (Utenkova, 2018; Nozdracheva et al., 2019). In 2017, more than 20,000 cases of measles were reported in Europe, mainly in children (Nickovic et al., 2018, 2019). A high incidence of measles is observed in European countries 
with low immunization rates (in France, Germany, Italy, Romania, Poland, Switzerland, Ukraine) (Goncharov et al., 2019; Nickovic et al., 2019). Multiple increase in the incidence of measles in Europe remains to this day. In 2018 measles was registered on the American continent (Argentina, Brazil, Colombia, Ecuador, Mexico, Peru, Venezuela, Canada, and the United States) as well as in 28 European countries (Yunasova et al., 2019). In 2018, over 82,000 people were infected with measles in 47 countries out of 53, which is three times more than in 2017 and 15 times more than in 2016, with 72 fatal cases (Molochkova et al., 2019). In 2017, Ukraine was one of the top three among European countries in terms of measles. Romania and Italy shared the first and second places, respectively (Ishchuk \& Stetsyuk, 2018). According to the available data from the Public Health Center at the Ministry of Health of Ukraine in 2018, more than 54,000 people were diseased, among them being 34,000 children (Usachova et al., 2019). According to UNICEF, in 2018, Ukraine ranked first in terms of the measles incidence (Ishchuk \& Stetsyuk, 2018; Goncharov et al., 2019; Yunasova et al., 2019).

The leaders in the number of measles patients in 2018 in Ukraine were Lviv, Ivano-Frankivsk, Transcarpathian, Ternopil and Chernivtsi regions (Koloskova et al., 2019). In Ukraine, the increase in the incidence rate in recent years is primarily associated with low vaccination rates (Skryabina et al., 2018; Smyrnova et al., 2019). In 2016, only 45\% of children in Ukraine had measles vaccinations. Only 30\% of children received a second dose of the vaccine (Marusik, 2017; Savchuk et al., 2017; Usachova et al., 2019). In 2018, the number of children who received the first dose of live combination vaccine against measles, mumps (parotitis) and rubella (MMR) in time was $84.1 \%$, two doses $83.9 \%$ (Usachova et al., 2019). Despite having a safe and effective vaccine, vaccination programs have only covered worldwide about $85 \%$ of children under the age of one year with the first measles vaccine in 2014 (Ishchuk \& Stetsyuk, 2018; Portnoy et al., 2018). This is from a low mean index of $83 \%$ in the African region to a high mean index of 93\% in the American region (Freidl et al., 2018; Portnoy et al., 2018).

But for the formation of high measles immunity level among the population, the vaccination coverage should be more than $95 \%$ with two doses of measles vaccine (Fowlkes et al., 2016; Furuse \& Oshitani, 2017; Freidl et al., 2018).

In order to achieve measles elimination in five of the six WHO regions by 2020, efforts should be focused both on strengthening the planned vaccination program and on the possibility of supplementary immunization (SIA) of unvaccinated and not fully vaccinated with antimeasles vaccines to form immunity to measles in the population (Antipova et al., 2018; Orenstein et al., 2018; Portnoy et al., 2018). The same strategy has been adapted in the Southern African countries and has been a major contributor to the reported measles mortality decline in the African continent. WHO recommends repeating SIA every $2-4$ years for a country with the first vaccination coverage below $80 \%$ (Verguet et al., 2015).

Another strategy is to vaccinate children twice in infancy (Fowlkes et al., 2016; Zhanga et al., 2017; Hong et al., 2019). This regime, when used in Guinea and China, has resulted in high coverage, high antibody concentrations, excellent protection against measles, and increased survival of children by $30 \%$. Early vaccination efficacy with an early twodose regimen during a severe measles epidemic in Florida was $99 \%$ (Njie-Jobe et al., 2012). In China, children are also vaccinated twice in childhood at the age of 8 months and from 18 to 23 months (Zeng et al., 2019). As a result, the incidence of measles has fallen sharply: from 99.5 cases per million in 2008 to 7.4 in 2011 (Hao et al., 2016). Protective antibodies are transferred transplacentally during pregnancy and through breast milk if the mother has had measles or is fully vaccinated (Nickovic et al., 2018, 2019). Early weaning leads to depriving the child of measles antibodies, so the first vaccination should be carried out from the age of 6-9 months to 12 months. In addition, there is a call to consider planning an earlier age for the first dose of measles vaccine in $\mathrm{Eu}-$ rope (Park et al., 2016; Cilleruelo et al., 2017). However, studies in the United States have shown that cell-mediated responses to the measles vaccine administered to infants aged 6 months were similar to those in children vaccinated at 9 or 12 months of age, but antibody responses were reduced by maternal antibodies. Some children whose mothers were vaccinated and not naturally infected with measles lose their maternal antibodies long before their babies reach this age (Njie-Jobe et al., 2012; Cilleruelo et al., 2017). Therefore, it is necessary to study the duration and to perform quantitative analysis of maternal anti-measles antibodies in infants and to review the first vaccination terms (Park et al., 2016).

Not only does untimely vaccination contribute to the spread of measles, but also migration of the population, as well as nosocomial transmission of infection among patients and healthcare professionals (Hao et al., 2016; Vemula et al., 2016; Yunasova et al., 2019).

In view of the worsening of the measles epidemic situation and of the inability to achieve elimination targets within the established time limit, WHO and its partners within the Measles and Rubella Initiative have developed the Measles and Rubella Global Strategic Plan 20122020. It presented a strategy aimed at reducing global measles mortality by at least $95 \%$ by 2015 compared to 2000 levels and at achieving elimination of measles and rubella in at least five WHO regions by 2020 (O'Connor et al., 2017; Datta et al., 2018; Orenstein et al., 2018). Support for high measles vaccination coverage, rapid implementation of measures against measles outbreaks remain essential to prevent the wide spread of measles (Gastanaduy et al., 2018; Pozdnyakov \& Chernyavskaya, 2018; Patel et al., 2019).

Measles is a serious threat to the health and life of children and the adult population. Children at birth (even congenital measles is possible) and adults at any age can be infected with measles. Measles presents a risk of development of the severe course of the disease affecting the bronchopulmonary system (pneumonia, obstructive bronchitis, stenosing laryngotracheobronchitis); ENT (ear, nose, and throat) organs (sinusitis, otitis) complications, damage to other organs and systems (Moss, 2017; Nickovic et al., 2019). A particularly severe measles complication is nervous system impairment - from fulminant encephalopathy to severe encephalitis, meningoencephalitis, encephalomyelitis and polyradiculoneuritis. The measles virus is also considered to be involved in the development of chronic subacute sclerosing panencephalitis (SSPE), which can develop a few years after measles (Trykhlib et al., 2018). Measles remains one of the leading causes of death among infants worldwide, despite the availability of a safe and effective vaccine (Datta et al., 2018; Hong et al., 2019). Development of the severe course and complications of measles, particularly among pediatric patients, the lack of specific etiotropic treatment, makes the problem of knowing the features of the clinical course of measles, timely diagnosis and active prevention of this vaccine-manageable disease most urgent in the modern period.

The purpose of the research work is to study the clinical features of measles in children during the outbreak of 2018-2019 in the city of Mariupol, Donetsk region, Ukraine.

\section{Materials and methods}

A total of 212 children patients with measles who live in environmentally unfavourable industrial Donetsk region and were treated in the pediatric infectious disease department of the I. K. Matsuk City Hospital No. 4 in Mariupol during the epidemic outbreak of 2018-2019 were included in this study. Informed consent to participation in the study was obtained from the children's parents.

All children underwent conventional clinical and laboratory examination (clinical blood test, biochemical blood count, urine test).

Laboratory studies of antibodies to the measles virus were carried out on the basis of the Mariupol city state institution "Donetsk Regional Laboratory Center" under the Ministry of Health of Ukraine, at the "VectoKor-IgM" virological laboratory with a kit of reagents for immuno-enzymic detection of class $\mathrm{M}$ immunoglobulins to the measles virus in the blood serum (produced by AT "Vector-Best", Novosibirsk Russia, certified in Ukraine). The test system is used according to the instruction leaflet.

Initially, the test-system was calibrated with determining the critical value of IgM optical density (critical Optical Density $-\mathrm{OD}_{\text {crit }}$ ) calculated according to the formula: $\mathrm{OD}_{\text {cit }}=\mathrm{OD}_{\text {meanK }}+0.2$, where $\mathrm{OD}_{\text {meanK }}$ is calculated as the mean value of the negative control test-system samples, the value of which must not exceed 0.25 absorbance unit (AU). 
The rules for serological examination of patients with suspected measles were observed (Utenkova, 2018). The blood serum was selected on days 4-5 from the rash onset, and not later than day 28 from the moment of the rash onset. Persons vaccinated within the 6 months period were not subject to examination. The result is considered positive if the patient's index - ODs (where ODs is Optical Density of the analyzed sample) exceeded or was equal to $\mathrm{OD}_{\text {citit; }}$ negative - if ODs was less than $0.8 \mathrm{xOD}_{\text {citi }}$; undefined - if its value exceeded $0.8 \mathrm{xOD}_{\text {crit }}$, but does not exceed $\mathrm{OD}_{\text {cit }}$.

Comparisons are made of indices in different age groups (infants under one year, preschool and schoolchildren), in vaccinated and unvaccinated children, in children with measles complications and those without complications. According the vaccination, all patients are divided into groups: "vaccinated" - those who received the vaccination according to the schedule in full (2 vaccinations - at the age of 1 and 6 years); "vaccinated with a schedule change" - those who received 2 vaccinations, but at the wrong age; "partially vaccinated" - children who had received 1 vaccination according to the schedule at the age of 1 year or up to 6 years and those who had not received a revaccination, aged over 6 years; "unvaccinated before 1 year"; and "unvaccinated aged over 1 year".

Mean values $(\mathrm{x})$ and confidence interval for mean $(\mathrm{CI})$ were calculated to provide the data. Statistical processing of absolute values was performed in compliance with conventional methods with the calculation of intensive and extensive indices. Statistically significant difference is considered at $\mathrm{P}<0.05$ (ANOVA).

\section{Results}

In total 212 children with measles were monitored. In all patients the diagnosis of measles was established on the basis of epidemiological history, complaints, characteristic clinical symptoms, as well as positive results of IgM antibodies determination in serum by means of enzymelinked immunosorbent assay, which indicates the presence of acute infection.

In 2018, 2 children $(0.9 \%)$ came down with measles in October, 33 $(15.6 \%)$ - in November, and $26(12.3 \%)$ - in December. Among 212 patients with measles, the largest number of hospitalizations were in January 2019 - 56 (26.4\%) children, in February - 40 (18.9\%) and in March - 41 (19.3\%). In April, May and June 2019, the number of diseased children became small and the outbreak reached its end (Fig. 1).

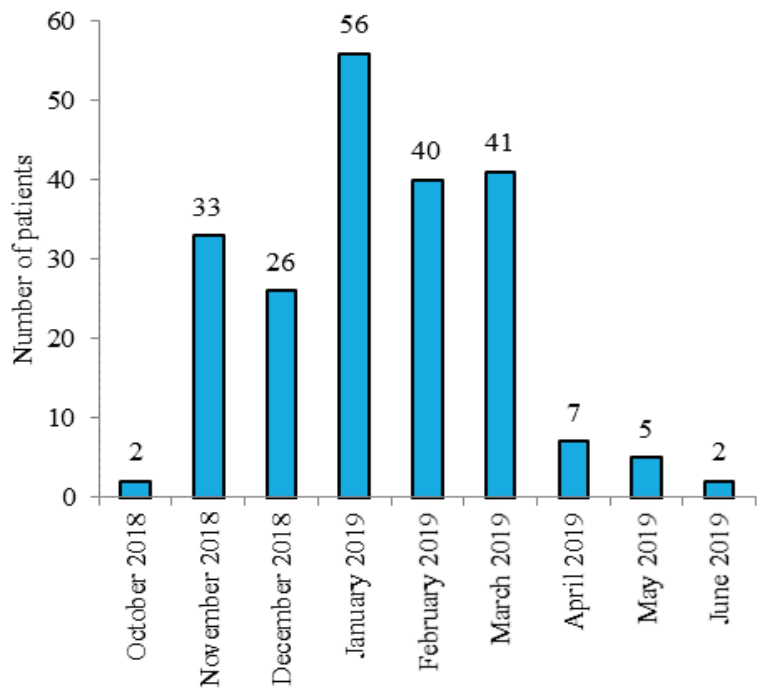

Period of measles outbreak

Fig. 1. Monthly incidence of measles infection during the 2018-2019 epidemic in Mariupol, Donetsk region, Ukraine

There were 112 (53\%) boys and 100 (47\%) girls among the hospitalized children. The patients' age ranged from 2 months to 18 years, with the mean age of $72.0 \pm 8.0$ months. The number of diseased child- ren under the age of 1 year was 64 (30.2\%), children of preschool age $64(30.2 \%)$, children of school age $-84(39.6 \%$, Fig. 2$)$.

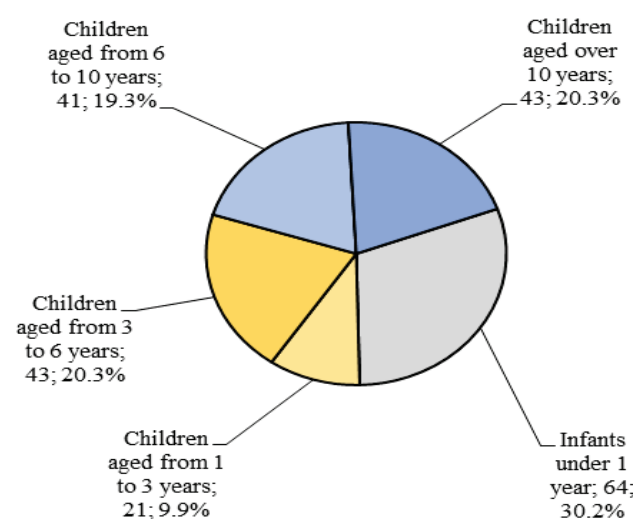

Fig. 2. Age characteristics of children diseased with measles during the outbreak of 2018-2019 in the city of Mariupol, Donetsk region, Ukraine

Breast-fed children under one year of age are considered protected from measles if their mothers are vaccinated against the measles or have had the disease before. But in the children under 1 year only $7(16.3 \%)$ were breast-fed. Most measles diseased children under the age of 1 year were non-breastfed infants - $36(83.7 \%)$. A total of 115 children $(54.2 \%)$ attended children's educational or care institutions: kindergarten $-26(12.3 \%)$, school $-65(30.6 \%)$, boarding school $-5(2.4 \%)$, specialized school - 19 children $(8.9 \%)$. There were 97 children not attending school or kindergarten (45.8\%), but most of them either were in contact with diseased children or lived in an apartment house where adults or children are diseased. Given the high contagiousness of the disease, it should be noted that 2-3 children from the same family were treated in hospital, there were 13 such families.

Vaccination had not been given to 111 children (52.3\%), including 64 children under 1 year of age (30.1\%) and 47 children over 1 year (22.2\%). Vaccination was performed partially: 1 dose of MMR (measles, mumps (parotitis), rubella) was administered to $30(14.2 \%)$ children; 1 dose of MMR with violation of the vaccination schedule - to $24(11.3 \%)$ children. According to the preventive vaccinations schedule, only 47 (22.2\%) children had been twice vaccinated with MMR.

The typical form of measles was characterized by cyclic course with changed classical periods (incubation, catarrhal, rash and pigmentation), presence of peculiar clinical syndromes of the disease. Catarrhal syndrome occurred in $100 \%$ of patients and was characterized by dry cough, nasal stuffiness, moderate mucous discharge from the nasal meatus, conjunctivitis (Table 1). Moderate hyperemia of the oropharynx mucous membranes $(100.0 \%)$ and enanthema was manifested in the soft and hard palate in the form of large red-coloured patches (64; $30.2 \%$ ). Enanthema was not detected in a single school-aged child (Table 2). Scleroconjunctivitis with specific light phobia was observed in $118(55.7 \%)$ patients, 204 (96.3\%) patients suffered coughing, rhinorrhea - in $180(84.9 \%)$ children. A pathognomonic symptom of measles infection - Koplik's spots (in the national literature - BelskyFilatov-Koplik spots) was only observed in $86(40.6 \%)$ patients, 3 times more frequently in children under 6 years of age than in school children $(\mathrm{P}$ $<0.05$, Table 1, 2). But the detection of this pathognomonic symptom of measles depends on the time of the diseased child's admission to hospital.

Fever was observed in almost all the patients $(201 ; 94.8 \%)$. Body temperature fluctuations in the patients ranged from 37.1 to $40.3{ }^{\circ} \mathrm{C}$. In almost half of the patients $(105 ; 49.5 \%)$, the maximum temperature exceeded $38.0^{\circ} \mathrm{C}$. In 11 (5.2\%) children, fever was not observed; these were 4 children vaccinated with 2 doses of MMR and 4 children who had 1 dose of MMR, 3 more breast-fed children under 1 year of age (Table 1). Measles can also occur in vaccinated children, but the presence of protective immunity is indicated by the mild course of the disease and by rare development of complications. These children endured an atypical mild form of the disease - mitigated measles, they have mild catarrhal phenomena, Belsky-Filatov-Koplik spots were absent, rash 
was slight, unclear, disturbed stages of the rash that developed in an unusual manner (the rash comes simultaneously on the face and trunk, or starts with the extremities and lower body). The mean fever duration was 3.8 days ( $3.8 \pm 0.4$ days, 1 to 12 days). No significant difference was observed in the level and duration of fever between different age groups of patients $(\mathrm{P}>0.05)$. In children vaccinated with the measles vaccine, the fever duration was $3.6 \pm 0.5$ days (1-12 days). The fever duration was slightly longer in patients who had not received measles vaccination ( $4.3 \pm 0.6$ days $)$ compared to vaccinated children $(3.6 \pm 0.5$ days, $\mathrm{P}>0.05)$ and in children who had complications ( $4.6 \pm 0.8$ days) compared to patients without complications $(3.9 \pm 0.4, \mathrm{P}>0.05)$. The mean body temperature level was $37.8 \pm 0.1{ }^{\circ} \mathrm{C}$, there was no significant temperature level difference in vaccinated and unvaccinated children (37.9 \pm 0.2 and $37.8 \pm 0.2^{\circ} \mathrm{C}$ respectively, $\mathrm{P}>0.05$ ), but in children with complications the mean temperature was $38.5 \pm 0.2^{\circ} \mathrm{C}$ and exceeded that in children without complications $\left(37.8 \pm 0.2^{\circ} \mathrm{C}, \mathrm{P}<0.05\right)$.

The height of the disease is manifested in abundant exanthema, prone to fusion with the formation of erythematous areas. The rash was present in all the patients and in all cases $(100 \%)$ was spotty-papular.
Only 2 children aged 9 and 10 years old had a hemorrhagic component in the rash. The rash came on average in $4.0 \pm 0.2$ days, regardless of the child's vaccine status (in non-vaccinated patients - on days $3.9 \pm$ 0.4 day and in vaccinated ones - on days $4.1 \pm 0.3, \mathrm{P}>0.05$ ). In 170 $(80 \%)$ patients, the stage of rash with a characteristic spread from head to extremities was observed within 3-4 days.

In $42(20 \%)$ patients vaccinated with 2 or 1 dose of MMR, the rash stage was impaired, i.e. in 11 (5.2\%) children the rash starts with lower extremities, or in 31 (14.8\%) child - with face and trunk together.

In the same manner as the rash onset, i.e. from the face to the lower extremities, pigmentation appeared in patients with a typical clinical picture (148; 69.8\%). Pigmentation and skin itching were absent in children under 1 year $(\mathrm{P}<0.05)$. Skin sloughing was only detected in $22(10.4 \%)$ school-aged children $(\mathrm{P}<0.05)$. Skin rash and desquamation were accompanied by slight itching in 85 patients over 1 year aged (40.1\%). Itching was 2 times more common in children of school age than in children of preschool age, and it was not found in children up to 1 year $(67.1 \%$ and $32.9 \%$ respectively, $0 \%-$ after 1 year of age $(\mathrm{P}<0.05)$.

\section{Table 1}

Incidence of major clinical symptoms of measles in infants under one year, preschoolers and schoolchildren

\begin{tabular}{|c|c|c|c|c|c|c|c|c|}
\hline \multirow{2}{*}{ Clinical symptom } & \multicolumn{2}{|c|}{ All children, $n=212$, } & \multicolumn{2}{|c|}{ Infants under 1 year, $n=64$} & \multicolumn{2}{|c|}{ Preschoolers aged $1-6$ years, $n=64$} & \multicolumn{2}{|c|}{ Schoolchildren aged $6-18$ years, $n=84$} \\
\hline & $\mathrm{N}$ & $\mathrm{P} \%$ & $\mathrm{n}_{1}$ & $\mathrm{p}_{1} \%$ & $\mathrm{n}_{2}$ & $\mathrm{p}_{2} \%$ & $\mathrm{n}_{3}$ & $\mathrm{p}_{3} \%$ \\
\hline Rhinorrhea & 180 & 84.9 & 32 & 17.8 & 64 & 35.6 & 84 & 46.7 \\
\hline Scleroconjunctivitis and photophobia & 118 & 55.7 & -** & -** & 56 & 47.5 & 62 & 52.5 \\
\hline Cough & 204 & 96.3 & 56 & 27.4 & 64 & 31.4 & 84 & 41.2 \\
\hline Koplik spots & 86 & 40.6 & 11 & 12.8 & 55 & $63.9^{*}$ & 20 & 23.3 \\
\hline Enanthema & 64 & 30.2 & 16 & 25.0 & 48 & $75.0^{*}$ & 0 & 0.0 \\
\hline Abdominal pain, diarrhea & 64 & 30.2 & 18 & 28.1 & 46 & $71.9^{*}$ & 0 & 0.0 \\
\hline Fever & 201 & 94.8 & 61 & 30.4 & 62 & 30.8 & 78 & 38.8 \\
\hline Fever $>38^{\circ} \mathrm{C}$ & 105 & 49.5 & 25 & 23.8 & 45 & 42.9 & 35 & 33.3 \\
\hline Spotty-papular rash & 212 & 100.0 & 64 & 30.2 & 64 & 30.2 & 84 & 39.6 \\
\hline Rash hemorrhagic component & 2 & 0.9 & 0 & 0.0 & 0 & 0.0 & 2 & 100.0 \\
\hline Staged rash onset & 170 & 80.0 & 46 & 27.1 & 51 & 30.0 & 73 & 42.9 \\
\hline Skin pigmentation & 148 & 69.8 & 0 & 0.0 & 64 & 43.2 & 84 & 56.8 \\
\hline Skin sloughing & 22 & 10.4 & 0 & 0.0 & 0 & $0.0^{*}$ & 22 & 100.0 \\
\hline Skin itching & 85 & 40.1 & 0 & 0.0 & 28 & $32.9^{*}$ & 57 & 67.1 \\
\hline
\end{tabular}

Note: $\mathrm{N}$ - number of all children, who had symptom; $\mathrm{P} \%$ - percentage of patients with symptom from all children under monitoring; $\mathrm{n}_{1}-$ number of infants under 1 year, who had symptom; $\mathrm{p}_{1} \%$ - percentage of infants under 1 year, who had symptom from all children who had symptom; $\mathrm{n}_{2}-$ number of preschoolers aged $1-6$ years who had symptom; $\mathrm{p}_{2} \%$ - percentage of preschoolers aged $1-6$ years who had symptom from all children; $\mathrm{n}_{3}$ - number of schoolchildren aged 6-18 years who had symptom; $\mathrm{p}_{3} \%$ - percentage of schoolchildren aged 6-18 years who had symptom from all children who had symptom; $*$ - reliability of the indices difference between children aged 1-6 years and schoolchildren $\mathrm{P}<0.05 ; * *$ - undetectable at this age.

Table 2

Incidence of major clinical symptoms of measles in patients of different age groups

\begin{tabular}{|c|c|c|c|c|c|c|c|c|c|c|}
\hline \multirow{2}{*}{ Clinical symptom } & \multicolumn{2}{|c|}{ under 1 year, $n=64$} & \multicolumn{2}{|c|}{$1-3$ years, $n=21$} & \multicolumn{2}{|c|}{$3-6$ years, $n=43$} & \multicolumn{2}{|c|}{$6-10$ years, $n=41$} & \multicolumn{2}{|c|}{$>10$ years, $n=43$} \\
\hline & $\mathrm{n}_{1}$ & $\mathrm{p}_{1} \%$ & $\mathrm{n}_{1}$ & $\mathrm{p}_{1} \%$ & $\mathrm{n}_{1}$ & $\mathrm{p}_{1} \%$ & $\mathrm{n}_{1}$ & $\mathrm{p}_{1} \%$ & $\mathrm{n}_{1}$ & $\mathrm{p}_{1} \%$ \\
\hline Rhinorrhea & 32 & 17.8 & 21 & 11.6 & 43 & 23.9 & 41 & 22.8 & 43 & 23.9 \\
\hline Scleroconjunctivitis and photophobia & 0 & 0.0 & 13 & 11.0 & 43 & 36.4 & 41 & 34.8 & 21 & 17.8 \\
\hline Cough & 56 & 27.4 & 21 & 10.3 & 43 & 21.1 & 41 & 20.1 & 43 & 21.1 \\
\hline Koplik spots & 11 & 12.8 & 20 & 23.3 & 35 & 40.7 & 15 & 17.4 & 5 & 5.8 \\
\hline Enanthema & 16 & 25.0 & 20 & 31.3 & 28 & 43.7 & 0 & 0.0 & 0 & 0.0 \\
\hline Abdominal pain, diarrhea & 18 & 28.1 & 18 & 28.1 & 28 & 43.8 & 0 & 0.0 & 0 & 0.0 \\
\hline Fever & 61 & 30.4 & 21 & 10.4 & 41 & 20.4 & 39 & 19.4 & 39 & 19.4 \\
\hline Fever $>38^{\circ} \mathrm{C}$ & 25 & 23.8 & 21 & 20.0 & 24 & 22.9 & 16 & 15.2 & 19 & 18,1 \\
\hline Spotty-papular rash & 64 & 30.2 & 21 & 9.9 & 43 & 20.3 & 41 & 19.3 & 43 & 20.3 \\
\hline Rash hemorrhagic component & 0 & 0.0 & 0 & 0.0 & 0 & 0.0 & 2 & 100.0 & 0 & 0.0 \\
\hline Staged rash onset & 46 & 27.1 & 15 & 8.8 & 36 & 21.2 & 35 & 20.6 & 38 & 22.3 \\
\hline Skin pigmentation & 0 & 0.0 & 21 & 14.2 & 43 & 29.1 & 41 & 27.7 & 43 & 29.0 \\
\hline Skin sloughing & 0 & 0.0 & 0 & 0.0 & 0 & 0.0 & 10 & 45.4 & 12 & 54.6 \\
\hline Skin itching & 0 & 0.0 & 0 & 0.0 & 28 & 32.9 & 32 & 37.7 & 25 & 29.4 \\
\hline
\end{tabular}

Note: $\mathrm{n}_{1}-$ number of all children who had symptom in specified age; $\mathrm{p}_{1} \%$ - percentage of patients in specified age with symptom from all children who had this symptom.

The rash onset was accompanied by a new rise in body temperature. The intoxication syndrome was most pronounced in the first 2 days of the rash period and was characterized by sedation, decreased liveliness of patients, tearfulness, refusal to eat and drink (201; 94.8\%). One third (64; $30.2 \%$ ) of the children under 6 years of age experienced moderate abdominal pain and loose stool 3-4 times a day against the onset of rash.

The measles severity can have a mild, moderate and severe course (Fig. 3). The disease severity is determined taking into account the presence and severity of general intoxication symptoms, height and duration of the temperature response, the degree of the upper respiratory tract and eyes damage, nature and duration of rash, presence of complications. Only 2 patients with measles $(0.9 \%)$ vaccinated with 1 or 2 MMR doses had a mild disease course. Children with mild measles are also likely to have been treated at home. Most of the children were hospitalized in a pediatric infectious department with moderately severe course (148; 69.8\%). Severe measles was found in $62(29.3 \%)$ patients. The severe disease course was observed in all age groups, but children up to 1 year of age and preschool children with severe course were two times as numerous as school 
children. In MMR vaccinated children, $27(26.7 \%)$ patients had severe disease course, and $35(31.5 \%)$ patients $(\mathrm{P}>0.05)$ were non-immunized with MMR (Fig. 4). The onset of complications is manifested by a new fever and worsening of the child's general condition or a fever that does not decrease after 4-5 days. In measles, pulmonary, nervous, and digestive systems and ENT organs complications occur most frequently. Complications were found in $60(28.3 \%)$ patients (Table 3 ).

Fluctuations in the incidence of complications depending on the child's age are not statistically significant. The frequency of complications does not also depend on the child's vaccinal status $(\mathrm{P}>0.05)$. Most of the complications are related to the respiratory tract organs. Pneumonia com- plicated the course of measles in $23(38.3 \%)$ patients. In all cases, pneumonia was confirmed radiographically. Among 23 patients with pneumonia under 1 year of age, there were 5 infants, those $1-3$ years -3 children, $3-6$ years -5 , and 6-10 years -6 , 10 years and older -4 children. Rare complications of measles are pneumothorax; pneumomediastinum; subcutaneous emphysema and others. In one patient, pneumonia was complicated by subcutaneous emphysema, severe respiratory failure that required treatment of the child in the intensive care unit. Bronchitis was observed in $33(53.2 \%)$ children. Laryngitis was observed in $2(3.3 \%)$ patients. Bacterial complications of ENT organs (otitis media) were detected in $3(5 \%)$ patients. Intestinal disorders were observed in $64(30.2 \%)$ patients.

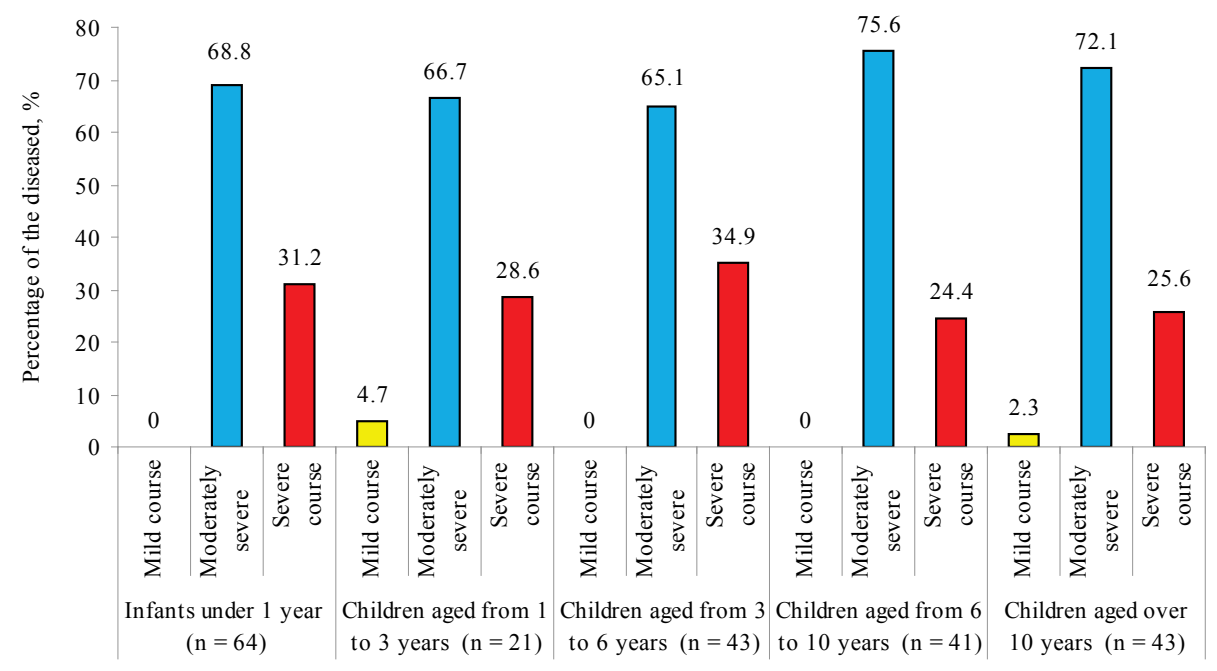

Fig. 3. Distribution of diseased children by age and severity of measles during the outbreak of 2018-2019 in the city of Mariupol (Ukraine)

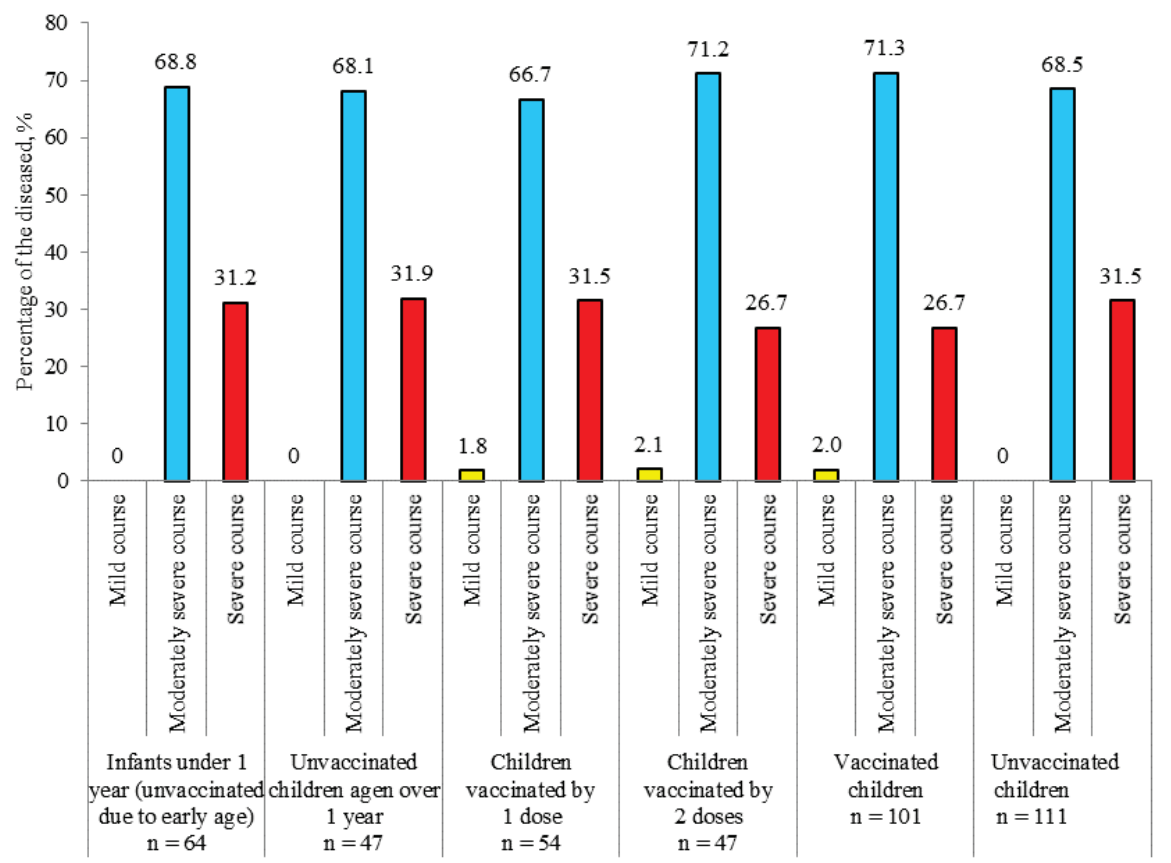

Fig. 4. Distribution of diseased children by severity of measles and vaccination status during the outbreak of 2018-2019 in the city of Mariupol (Ukraine)

Among our patients were children having several complications, namely: pneumonia complicated by subcutaneous emphysema, and almost all children with pneumonia had intestinal disorders. There were no nervous system complications in the children hospitalized in the pediatric infectious department.

Laboratory examination revealed fluctuations in the level of peripheral blood leukocytes in patients amounting $4.1-12.8 \mathrm{G} / \mathrm{L}\left(10^{9} / \mathrm{L}\right)$, the mean level was $7.0 \pm 0.2 \mathrm{G} / \mathrm{L}$. Leukopenia, one of the most common laboratory symptoms of measles, was not observed in any patient. Almost half of the patients had normocytosis in their blood tests. Neutrophilia was observed in $136(64.2 \%)$ patients. The percentage of stab neutrophils increased to the maximum of $31 \%$ in children with complications, the mean level of stab neutrophils was $9.5 \pm 0.9 \%$. The mean ESR (Erythrocyte sedimentation rate) was $14.5 \pm 1.1 \mathrm{~mm} / \mathrm{h}$, with the maximum of $25 \mathrm{~mm} / \mathrm{h}$. The mean level of serum anti-measles IgM antibodies detected by the enzyme immunoassay amounted to $2.55 \pm 0.06 \mathrm{AU}$ (absorbance unit), it did not differ significantly between vaccinated and unvaccinated children (2.6 \pm 0.1 and $2.5 \pm 0.1 \mathrm{AU}, \mathrm{P}>0.05$ ).

The duration of inpatient treatment for measles patients ranged 6 20 days ( $8.8 \pm 0.4$ days). The mean length of stay in hospital did not depend on the child's age. Thus, it amounted to $9.2 \pm 0.6$ days in infants under one year of age, in children of preschool and school age $-9.1 \pm$ 
0.7 days and $8.5 \pm 0.6$ days, respectively $(\mathrm{P}>0.05)$. The mean length of staying in hospital depended on the presence of complications. Thus, patients with complications were hospitalized for $10.0 \pm 0.6$ days, those without complications - for $8.2 \pm 0.3$ days $(\mathrm{P}<0.05)$.

Table 3

Structure of complications in children with measles

\begin{tabular}{lcc}
\hline \multicolumn{1}{c}{ Measles complications } & \multicolumn{2}{c}{ Number of patients $\mathrm{n}=212$} \\
& $\mathrm{n}_{1}$ & $\mathrm{p}_{1} \%$ \\
\hline Pneumonia & 23 & 38.3 \\
Subcutaneous emphysema & 1 & 1.7 \\
Bronchitis & 33 & 53.2 \\
Laryngitis & 2 & 3.3 \\
Otitis & 3 & 5.0 \\
Intestinal disorders & 64 & 30.2 \\
\hline
\end{tabular}

Note: $\mathrm{n}_{1}$ - number of all children who have complication; $\mathrm{p}_{1} \%$ - percentage of patients who have complication from all children under monitoring.

\section{Discussion}

In recent years, the incidence of measles has shown a number of features. Age priority has ceased, i.e., this infection has lost its infant status, and affects all age categories with a dominant shift to 14-25 year olds (O'Connor et al., 2017; Volanska et al., 2019) and priority in adults (Pokrovska et al., 2015; Goncharov et al., 2019). Volyanska et al. (2019) indicate that the shift of the morbidity peak in the Ternopil region to the age group of 14-25 year olds actualizes the necessity of revaccination against measles at this age, because they have a high risk of catching the disease due to the weakening of the post-vaccination immunity over the years. The levels of measles antibodies decrease with increasing time after vaccination, suggesting that measles susceptibility is potentially increasing (Kang et al., 2017).

The works of Clemmons et al. (2017), Skryabina et al. (2018), Nickovic et al. (2019) report an increase in the proportion of diseased schoolchildren aged 6-14 and adolescents. According to Usacheva et al. (2019) the proportion of children aged 1-9 years of all measles diseased children in the Zaporizhzhya region is $72 \%$, in the Carpathian region diseased children of this age amount to $64.8 \%$, which indicates low vaccination coverage (Savchuk et al., 2017). In the Odessa region, the vast majority of patients are children aged $1-4$ and 5-9 years, as well as persons in the age group over 30 years (Goncharov et al., 2019).

Kharchenko \& Kimirilova (2019) point out to high susceptibility to measles in infants under 3 years of age, $76 \%$ of measles cases are attributed to this age group. The incidence of measles among infants is increasing due to the lack of immunity (post-vaccination or post-infection) in their mothers (Clemmons et al., 2017; Patel et al., 2019; Volyanska et al., 2019). According to our study, pre-school children $(60.4 \%)$ are the most prevalent among patients with measles, including $30.2 \%$ - under 1 year of age, $30.2 \%-1-6$ years, which is consistent with Jahic et al. (2017) - 57.2\%.

The number of vaccinated patients is increasing. Our data is consistent with that of Volyanska et al. (2019), with regard to epidemic rates of measles incidence in the Ternopil region, where a high percentage of vaccinated persons, about $50 \%$, is registered among patients. In our study, $47.7 \%$ of children with measles were vaccinated. Data in the Odessa region indicate that this index is much lower $-5-15 \%$ (Goncharov et al., 2019). According to the Russian authors Kharchenko \& Kimirilova (2019) the proportion of vaccinated children is $26.7 \%$.

The incidence rate is determined by the coverage of the infant population with schedule vaccinations (Volyanska et al., 2019). According to the published studies (Jahic et al., 2017; Savchuk et al., 2017; Patel et al., 2019) the majority of measles patients are unvaccinated children (49.4-76.7\%). In studies of Timchenko et al. (2015), almost all children with measles were unvaccinated (95.4\%). In Mariupol (the Donetsk region), $52.3 \%$ of the diseased children were not vaccinated. The results of this study and the literature sources indicate that the majority of patients are unvaccinated children, which caused the epidemic outbreak.

Measles in all the age groups of children, both vaccinated and unvaccinated, typically occurred with a predominance of moderately seve- re course of the disease. Our results in terms of the disease severity do not have significant differences with data from other studies (Pavelkina et al., 2016; Skryabina et al., 2018; Smyrnova et al., 2019). Analysis of the obtained data shows that the severe course of the disease $(29.3 \%)$ occurs at all ages, but among children with severe course there are two times more infants up to one year and preschool children than schoolchildren (64.5\% and 35.5\% respectively). Kramarov et al. (2018) and Yevtushenko et al. (2019) report that the disease severity does not depend on the child's age.

According to our data, the most common disease type in hospitalized children was the moderately severe measles course $(69.8 \%)$. Almost all the children had fever (94.8\%), rhinorrhea (84.9\%), cough (96.3\%), as reported by most authors (Pokrovska et al., 2015; Timchenko et al., 2017; Moss, 2017). We found that half of the children had scleroconjunctivitis and photophobia (55.7\%), as in the work of Skryabina et al. (2018) - 46\%, Pavelkina et al. (2016) - 57.1\%, but in the studies of Pokrovska et al. (2015), Kramarov et al. (2018), Yevtushenko et al. (2019) scleroconjunctivitis and photophobia were more common (83.2-85.7\%) and were pronounced in schoolchildren and adults.

According to our observations, the pathognomonic symptoms of measles - enanthema (30.2\%) and Belsky-Filatov-Koplik spots (40.6\%) were three times more frequent in children under 6 years of age than in schoolchildren (63.9\% and $23.3 \%$, respectively, $\mathrm{P}<0.05)$. According to literature data (Pokrovska et al., 2015; Timchenko et al., 2017; Skryabina et al., 2018) Belsky-Filatov-Koplik spots are more frequently found, in $66.5-96.8 \%$ of patients. Kharchenko \& Kimirilova (2019) point out that Belsky-Filatov-Koplik spots are observed in $66.5 \%$ of patients, including half of the children under one year and $77.5 \%$ of schoolchildren. However, Nickovic et al. (2018) observed Belsky-Filatov-Koplik spots in only $6.4 \%$ of children with measles. According to various studies, the enanthema is found in $20-57 \%$ of cases (Pokrovska et al., 2015; Skryabina et al., 2018; Kharchenko \& Kimirilova, 2019).

During the rash stage, $100 \%$ of patients had a spotty-papular rash with a staged of onset $(80 \%)$ and a tendency to fuse, which coincides with the literature data (Pavelkina et al., 2016; Artemova \& Kulichenko, 2017).

The sign of the past measles disease is pigmentation $(69.8 \%)$, which is absent in children under one year of age, and skin sloughing, which was only observed in schoolchildren (10.4\%). Pokrovska et al. (2015) also report that pigmentation and skin sloughing are predominantly found in children aged over 15 years and in adults. Kharchenko \& Kimirilova (2019) observed pigmentation in $71.1 \%$ and skin sloughing in $35.4 \%$ of patients, mainly in schoolchildren. Timchenko et al. (2015) report skin sloughing in 14.7\% of infants with measles. Almost in all patients (92.7-100.0\%), pigmentation is revealed according to Timchenko et al. (2015), Pavelkina et al. (2016), Skryabina et al. (2018).

Smyrnova et al. (2019) report that in the epidemic season 20172018 in the Zaporozhye region they observed a relatively rare complication - hepatitis (54\%), which is probably related to the direct hepatotropic action of the measles virus. In these patients hepatomegaly without concomitant splenomegaly and ALT (Alanine aminotrasferrase) increase by $2-10$ times compared to the norm were found. During the 2010-2011 measles epidemic (Paris, France - Dinh et al., 2013), measles complications in the form of hepatitis $(37.5 \%)$ were also reported. Pavelkina et al. (2016) point out to the development of reactive hepatitis with hepatomegaly and cytolysis syndrome in $78.6 \%$ of patients. In their study, Jahic et al. (2017), Kramarov et al. (2018) and Yevtushenko et al. (2019) found hepatitis in only $1.20-1.43 \%$ of patients, with hepatic changes limited only by increased transaminase and not accompanied by clinical symptoms. However, we did not find liver enlargement in children with measles, transaminase levels were not studied.

In our patients, $30.2 \%$ of infants under one year of age and preschool children experienced intestinal disorders: abdominal pain and diarrhea, which is consistent with the literature data. Thus, Pokrovska et al. (2015), Nickovic et al. (2018), Kharchenko \& Kimirilova (2019) observed moderate abdominal pain and loose stool 3-4 times a day in $21.2-40.0 \%$ of infants up to three years of age against the background of rash, and explained it by the direct effect of the measles virus on the intestinal mucosa and by mesadenitis. 
According to Trykhlib et al. (2018) complications of measles were observed in $21-40 \%$ of patients. Timchenko et al. $(2015,2017)$ found complications of measles in children under one year in $36.4 \%$ of cases (pneumonia, otitis, etc.). We observed complications of measles in $29.3 \%$ of children. Among the revealed complications, the vast majority were associated with respiratory organs: pneumonia $(38.3 \%)$, subcutaneous emphysema (1.7\%), bronchitis (53.2\%), laryngitis (3.3\%), otitis media (5\%). In the studies of Jahic et al. (2017) pneumonia was similarly common in $38.8 \%$ and bronchitis was only found in $4.3 \%$ of children. According to Kramarov et al. (2018), Yevtushenko et al. (2019) measles complications were found in $15.7 \%$ of children, pneumonia and bronchitis were found only in $2.86 \%$ and $2.14 \%$ respectively, sinusitis and otitis - in $3.57 \%$ and $2.86 \%$. Kharchenko \& Kimirilova (2019) also indicate that complications were not severe and ended with recovery, pneumonia was detected in $2.4 \%$ of patients, bronchitis - in $7.6 \%$, otitis in 1.4\%. In our observation and according to Kramarov et al. (2018), Yevtushenko et al. (2019) the presence of complications and severe measles course are independent of the child's age and vaccinal status.

According to our data, leukopenia, which is one of the most common laboratory symptoms of measles, was not observed in any patient. Neutrophilia was observed in $64.2 \%$ of patients with stab neutrophil shifting of leukocyte formula to the left. In general blood analysis of patients with uncomplicated measles Pokrovska et al. (2015) revealed leukopenia with relative lymphocytosis in only $20.9 \%$ of adults and $25.7 \%$ of children, with no children under one year having leukopenia in any case, most often the normal number of leukocytes with stab neutrophil shifting of leukocyte formula to the left (63.4\%). Leukopenia or normocytosis is also reported by Utenkova (2018). Every fifth child with measles showed leukopenia within $4-6$ days of the disease onset according to Kramarov et al. (2018), Yevtushenko et al. (2019).

Measles in infants has its own features: conjunctivitis, photophobia, rhinitis are poorly pronounced, but cough is present in all children aged under one year, only half of infants have a staged rash onset, half of them have pigmentation, and one third have skin sloughing (Pokrovska et al., 2015). Timchenko et al. $(2015,2017)$ also indicate that catarrhal phenomena are not pronounced in infants, Belsky-Filatov-Koplik spots may be absent, rash is not abundant and pale, its onset is staged, pigmentation is poorly pronounced, intestinal dysfunction frequently occurs. According to our data, cough was present in one third of infants, while in one third there was a staged rash, no pigmentation and skin sloughing, one third had abdominal pain and diarrhea.

Thus, the revealed clinical features of measles in children during the outbreak of 2018-2019 in the city of Mariupol (Donetsk region) are very important for timely diagnosis of the disease and for the termination of outbreaks. Reducing the incidence of measles can be facilitated by the timely detection and isolation of measles patients, elimination of measles transmission into organized children's groups, prevention of nosocomial measles outbreaks in combination with routine double immunization against the measles of children and serologic immunity control in vaccinated children.

\section{Conclusions}

The peculiarity of the measles outbreak in 2018-2019 in Mariupol, Donetsk region, was the prevalence of the disease in preschool children (60.4\%), including 30.2\% under one year of age. The high incidence of measles is associated with low rates of vaccination in children. $52.3 \%$ of children had not been vaccinated. According to the preventive vaccinations schedule, only $22.2 \%$ of children had been administered MPR twice. Analysis of the clinical course of measles in children of different age groups, both vaccinated and unvaccinated, showed that measles in most cases $(69.8 \%)$ took a typical moderately severe form, characterized by cyclic course with changing classical periods: incubation, catarrhal, rash and pigmentation. In the clinical picture of measles in preschool and school age children there are definitive features. Thus, Belsky-FilatovKoplik spots were observed three times more frequently in preschool children than in schoolchildren ( $63.9 \%$ and $23.3 \%$, respectively, $\mathrm{P}<0.05$ ). Abdominal pain and diarrhea were only observed in children under 6 years of age (30.2\%). Skin pigmentation was absent in children under one year of age and was detected in preschool and school-age children $(69.8 \%, \mathrm{P}<0.05)$. Skin sloughing was only observed in schoolchildren (10.4\%). Leukopenia, which is one of the most common laboratory symptoms of measles, was not observed in any patient. In $64.2 \%$ of the patients, neutrophilia was observed with stab neutrophils shift of the leukocyte formula to the left. The mean serum anti-measles IgM antibody level detected by the immune-enzyme assay was elevated and made $2.55 \pm$ $0.06 \mathrm{AU}$ and did not differ between vaccinated and unvaccinated children $(\mathrm{P}>0.05)$. Severe disease course occurred in patients of all ages $(29.3 \%)$, but children aged under one year and preschool children with severe disease were two times more numerous than those of the school age. Among the observed complications, the vast majority were associated with the respiratory organs: pneumonia $(38.3 \%)$, subcutaneous emphysema $(1.7 \%)$, bronchitis $(53.2 \%)$, laryngitis $(3.3 \%)$ and otitis media $(5.0 \%)$. Vaccination is the only means of protection against measles. Forming a favourable attitude to immunization, restoring public trust in vaccination, using all forms and means of information is required.

\section{References}

Antipova, A. Y., Bichurina, M. A., \& Lavrentieva, I. N. (2018). K voprosu o realizacii programmy jeliminacii kori v stranah zapadno-tihookeanskogo regiona VOZ [Implementation of the world health organization Western-Pacific regional plan of action for measles elimination]. Infektsiya i Immunitet, 8(4), 465-472 (in Russian).

Artemova, I. V., \& Kulichenko, T. V. (2017). Eepidemija kori. Real'na li ugroza? [The epidemic of measles. Is the threat real?]. Voprosy Sovremennoj Pediatrii, 16(5), 358-361 (in Russian)

Bester, J. C. (2016). Measles and measles vaccination: A review. JAMA Pediatrics, 170(12), 1209-1215.

Cilleruelo, M. J., García, A. F., Villaverde, S., Echevarría, J., Marín, M. A., Sanz, J. C., Lópeza, A., Royuela, F., Antoran, B. R., \& Ory, F. (2017). Duration of immunity to measles, rubella and mumps during the first year of life. Vaccine, 37(30), 41644171.

Clemmons, N. S., Wallace, G. S., Patel, M., \& Gastañaduy, P. A. (2017). Incidence of measles in the United States, 2001-2015. JAMA, 318(13), 1279-1281.

Datta, S. S., O’Connor, P. M., Jankovic, D., Muscat, M., Mamou, M. C. B., Singh, S., Kaloumenos, T., Reef, S., Papania, M., \& Butlera, R. (2018). Progress and challenges in measles and rubella elimination in the WHO European Region. Vaccine, 36(36), 5408-5415.

Dinh, A., Fleuret, V., \& Hanslik, T. (2013). Liver involvement in adults with measles. International Journal of Infectious Diseases, 17(12), 1243-1244.

Doshi, R. H., Eckhoff, P., Cheng, A., Hoff, N. A., Mukadi, P., Shidi, C., Gerber, S., Okitolonda-Wemakoy, E., Tafum, J. J. M., Kominski, G. F., \& Rimoin, F. W. (2017). Assessing the cost-effectiveness of different measles vaccination strategies for children in the Democratic Republic of Congo. Vaccine, 35(45), 6187-6194.

Fowlkes, A. L., Witte, D., Beele, J., Audet, S. A., Broadhead, R., Bellini, W. J., Cutts, F., \& Helfand, R. F. (2016). Supplemental measles vaccine antibody response among HIV-infected and uninfected children in Malawi after 1- and 2-dose primary measles vaccination schedules. Vaccine, 34(12), 1459-1464.

Freidl, G. S., Tostmann, A., Curvers, M., Ruijs, W. L. M., Smits, S., Schepp, R., Duizer, E., Boland, G., Melker, H., Klis, F. R. M., Jeannine, L. A., Hautvast, C., \& Veldhuijzen, I. K. (2018). Immunity against measles, mumps, rubella, varicella, diphtheria, tetanus, polio, hepatitis A and hepatitis B among adult asylum seekers in the Netherlands, 2016. Vaccine, 36(12), 1664-1672.

Furuse, Y., \& Oshitani, H. (2017). Global transmission dynamics of measles in the measles tlimination era. Viruses, 9(4), 82.

Gastanaduy, P. A., Banerjeeb, E., DeBoltc, C., Bravo-Alcantarad, P., Samade, S. A., Pastord, D., Rotaa, P. A., Patela, M., Crowcroft, N. S., \& Durrheimg, D. N. (2018). Public health responses during measles outbreaks in elimination settings: Strategies and challenges. Human Vaccines and Immunotherapeutics, 14(9), 2222-2238.

Goncharov, V. O., Kotlik, L. S., Skopenko, O. V., Hruzevsky, O. A., \& Grydina, T. L. (2019). Epidemichni pokazniki shhodo koru v Odes'kij oblasti [Epidemiological indicators for measles in the Odesa region]. Aktual'naja Infektologija, 7(2), 76-82 (in Ukrainian).

Hao, L., Ma, C., Wannemuehler, K. A., Su, Q., An, Z., Caims, L., Quick, L., Rodewald, L., Liu, Y., He, H., Xu, Q., Ma, Y., Yu, W., Zhang, N., Li, L., Wang, N., Luo, H., Wang, H., \& Gregory, C. J. (2016). Risk factors for measles in children aged 8 months - 14 years in China after nationwide measles campaign: A multi-site case-control study, 2012-2013. Vaccine, 34(51), 6545-6552.

Hong, D. T., Hien, N. D., Thao, P. T. P., Anh, D. D., Mai, H. H., Huyen, D. T. T., Huong, N. L., Phuong, B. H., Iijima, M., Ito, T., \& Nakayamae, T. (2019). Immunogenicity of the AIK-C measles vaccine in infants aged $<9$ months in Vietnam. Vaccine, 37(32), 4576-4580. 
Ishchuk, I. S., \& Stetsyuk, I. O. (2018). Vakcinacija proti koru jak efektivna profilaktika viniknennja zahvorjuvannja [Vaccination against measles as an effective prophylaxis of the oncet of the disease]. Infekcijni Hvorobi, 93(3), 57-61 (in Ukrainian).

Jahic, R., Porobic-Jahic, H., \& Zepic, D. (2017). Epidemiological and clinical characteristics of children with mealsles hospitalized at the department for infectious diseases in Tuzia during the 2014-2015 measles epidemic. Central European Journal of Paediatrics, 13(1), 62-68.

Kang, H. J., Han, Y. W., Kim, S. J., Kim, Y. J., Kim, A. R., Kim, J. A., Jung, H. D., Eom, H. E., Park, O., \& Kim, S. S. (2017). An increasing, potentially measlessusceptible population over time after vaccination in Korea. Vaccine, 35(23), 4126-4132.

Kharchenko, G. A., \& Kimirilova, O. G. (2019). Kliniko-epidemiologicheskie osobennosti kori u detej Astrahanskoj oblasti [Clinical and epidemiological features of the Measles in children of the Astrakhan region]. Detskie Infektsii, 18(3), 3136 (in Russian).

Koloskova, O. K., Ivanova, L. A., Polishchuk, M. I., Gopko, N. V., \& Garas, M. N. (2019). Vrodzhenij kir (klinichnij vipadok) [Congenital measles (clinical case)] Zdorov'e Rebenka, 14, 40-43 (in Ukrainian).

Kramarov, S. O., Yevtushenko, V. V., Kovalyukh, I. Y., Kaminska, T. M., \& Golovach, O. V. (2018). Klinichna kartina koru v ditej, gospitalizovanih pid chas spalahu 2017-2018 rr. [Clinical features of measles in children hospitalized during 2017-2018 outbreak]. Aktual'naya Infektologiya, 6(5), 240-245 (in Ukrainian).

Marusik, U. I. (2017). Kir u ditej [Measles in children]. Aktual'naya Infektologiya, 5, 129-133 (in Ukrainian).

Molochkova, O. V., Kovalev, O. B., Shamsheva, O. V., Il'ina, N. O., Kosyreva, M. A Brunova, O. J., Mayatski, A. A., Korsunskij, A. A., Kashchenko, O. A., \& Galeeva, E. V. (2019). Bronholjogochnye oslozhnenija pri kori u detej (semejnyj sluchai) [Bronchopulmonary complications of measles in children (family case)]. Detskie Infektsii, 18, 42-48 (in Russian).

Moss, W. J. (2017). Measles. Lancet, 390(10111), 2490-2502.

Muscat, M., Shefer, A., Ben Mamou, M., Spataru, R., Jankovic, D., \& Deshevoy, S. (2014). The state of measles and rubella in the WHO European Region, 2013. Clinical Microbiology and Infection, 20(5), 12-18.

Nandi, A., Shet, A., Behrman, J. R., Black, M. M., Bloom, D. E., \& Laxminarayangh, R. (2019). Anthropometric, cognitive, and schooling benefits of measles vaccination: Longitudinal cohort analysis in Ethiopia, India, and Vietnam. Vaccine, 37(31), 4336-4343.

Nickovic, V., Kocic, B., Sulovic, L., Mitic, J., Jovanovic, S., \& Kocic, I. (2018). Epidemiological and clinical characteristics of children with morbilli in Serbian enclaves in Central Kosovo. Revue d'Épidémiologie et de Santé Publique, 66(Suppl. 5), 284.

Ničković, V., Sulović, L., Danić-Filipović, S., Marković-Jovanović, S., VujnovićŽivković, Z., Mitić, J., Kocić, H., \& Kocić, I. (2019). General, epidemiological parameters and immumization coverage of children suffering from morbilli in central Kosovo and Metohija. Acta Medica Medianae, 58(4), 32-40.

Njie-Jobe, J., Nyamweya, S., Miles, D. J. C., vd Sande, M., Zaman, S., Touray, E., Hossin, S., Adetifa, J., Palmero, M., Burl, S., Jeffries, D., Rowland-Jones, S. Flanagan, K., Jaye, A., \& Whittlea, H. (2012). Immunological impact of an additional early measles vaccine in Gambian children: Responses to a boost at 3 years. Vaccine, 30(15), 2543-2550.

Nozdracheva, A. V., Semenenko, T. A., Asatryan, M. N., Shmyr, I. C., Ershov, I. F. Solov'ev, D. V., Glinenko, V. M., \& Kuzin, S. N. (2017). Immunologicheskaja vospriimchivost' naselenija megapolisa k kori na jetape ee jeliminacii [Immunological susceptibility of metropolis population to measles in its elimination stage]. Epidemiologija i Vakcinoprofilaktika, 18, 18-26 (in Russian).

O'Connor, P., Jankovic, D., \& Muscat., M. (2017). Measles and rubella elimination in the WHO Region for Europe: Progress and challenges. Clinical Microbiology and Infection, 23(8), 504-510.

Orenstein, W. A., Cairns, L., Hinman, A., Nkowane, B., Olivé, J.-M., \& Reingold, A. L. (2018). Measles and Rubella Global Strategic Plan 2012-2020 midterm review report: Background and summary. Vaccine, 36(Suppl. 1), A35-A42.

Orenstein, W. A., Hinman, A., Nkowane, B., Olive, J. M., \& Reingold, A. (2018) Measles and Rubella Global Strategic Plan 2012-2020 midterm review. Vaccine, 36(Suppl. 1), A1-A34.

Park, S. H., Lee, D. H., Jin, J. Y., Shin, Y. L., Shin, M., Kim, S. S., Suh, W. S., Park, J. O., \& Hong, Y. H. (2017). Measles outbreaks in the Kyeongin area of the Republic of Korea, 2013-2014: A single-center experience in a country of measles elimination. Asian Pacific Journal of Tropical Medicine, 10(1), 69-74.

Patel, M., Lee, A. D., Clemmons, N. S., Redd, S. B., Poser, S., Blog, D., Zucker, J. R., Leung, J., Link-Gelles, R., Pham, H., Arciuolo, R. J., Rausch-Phung, E., Bankamp, B., Rota, P. A., Weinbaum, C. M., \& Gastañaduy, P. A (2019). National update on measles cases and outbreaks. Morbidity and Mortality Weekly Report, 68(40), 893-896.

Pavelkina, V. F., Markosyan, N. S., Ampleeva, N. P., Alferina, E. N., \& Almyasheva, R. Z. (2016). Kor' v Respublike Mordovii: Kliniko-epidemiologicheskie aspekty
[Measles in the Repablic of Mordovia: Clinical and epidemiological aspects]. Infekcionnye Bolezni: Novosti, Mnenija, Obuchenie, 3, 59-63 (in Russian).

Pham, V. H., Nguyet, D. P. H., Mai, K. N. H., Truong, K. H., Huynh, L. V., Pham, T. H. T., \& Abe, K. (2014). Measles epidemic among children in Vietnam: Genomic characterization of virus responsible for measles outbreak in Ho Chi minh City, 2014. Vaccine, 1(2-3), 133-140.

Pokrovska, T. V., Hnatiuk, V. V., \& Nadraha, O. B. (2015). Porivnjal'na harakteristika klinichnogo perebigu koru $\mathrm{v}$ ditej $\mathrm{i}$ doroslih [Comparative analysis of clinical course of measles in children and adults]. Infekcijni Hvoroby, 1, 28 32 (in Ukrainian).

Portnoy, A., Jit, M., Helleringer, S., \& Verguet, S. (2018). Impact of measles supplementary immunization activities on reaching children missed by routine programs. Vaccine, 36(1), 170-178

Pozdnyakov, A. A., \& Chernyavskaya, O. P. (2018). Projavlenija epidemicheskogo processa kori i krasnuhi na sovremennom jetape [Manifestations of the epidemic process of measles and rubella at the present stage]. Epidemiologija i Vakcinoprofilaktika, 17(5), 45-53 (in Russian).

Savchuk, R. M., Sidneva, N. I., Djus, T. B., Pogorila, L. Y., \& Stepanovich, A. M. (2017). Diagnostika koru na Prikarpatti: Vchora, s'ogodni, zavtra [Measles diagnosis at the Subcarpathian region: Yesterday, today, tomorrow]. Aktual'na Infektologia, 5(6), 265-267 (in Ukrainian).

Skryabina, S. V., Kovyazina, S. A., Kuzmin, S. V., Yurovskikh, A. I., Tsvirkun, O. V., Gerasimova, A. G., Tikhonova, N. T., Malyamova, L. N., Smimova, S. S., Kharitonov, A. N., \& Rybinskova, E. A. (2018). Vspyshka kori v Sverdlovskoj oblasti v 2016 godu [Measles outbreak in Sverdlovsk Region in 2016]. Epidemiologija i Vakcinoprofilaktika, 99, 50-56 (in Russian).

Smyrnova, D. D., Usachova, O. V., \& Firulina, O. M. (2019). Osoblivosti perebigu koru v epidsezoni 2017-2018 rr. - rozvytok asocijovanogo z virusom koru urazhennja pechinky [Features of epidemiological sesson 2017-2018 - development of liver lesion associated with measles virus]. Infekcijni Hvoroby, 95(1), 20-25 (in Ukrainian).

Timchenko, V. N., Chemova, T. M., Bublina, O. V., Pavlova, E. B., Nazarova, A. N., Leonicheva, O. A., \& Timofeeva, E. V. (2015). Kor' u detej rannego vozrasta [Measles in infants]. Detskie Infekcii, 14, 52-58 (in Russian).

Timchenko, V. N., Kaplina, T. A., Bunina, O. V., Leont'eva, O. A., Hakizimana, E. V., \& Timofeeva, E. V. (2017). Aktual'nye problemy korevoj infekcii [Actual problems of measles]. Pediatrija, 3(8), 120-129 (in Russian).

Trykhlib, V. I., Shchur, A. B., Hrushkevych, V. V., Hryshyn, O. S., Pavlovska, M. O., Musiienko, T. I., Muzyka, A. A., Ralets, N. V., Dudar, D. M., \& Kozachenko, L. V. (2018). Osoblivosti klinichnih projaviv ta perebigu koru [Peculiarities of measles clinical manifestations and course]. Aktual'na Infektologia, 6(3), 141152 (in Ukrainian)

Usachova, O. V., Silina, Y. A., Pakholchuk, T. N., Konakova, O. V., Dralova, O. A. Puhir, V. P., Firyulina, O. M., \& Zelenukhina, E. V. (2019). Kir-kerovana infekcija! Dejaki epidemiologichni paradigmi koru u Zaporiz'kij oblasti [Measles controlled infection! Some epidemiological paradigm of measles in Zaporizhzhia region]. Sovremennaja Pediatrija, 97, 13-18 (in Ukrainian).

Utenkova, E. O. (2018). Infekcionnye jekzantemy u detej [Infectious exanthema in children]. Detskiye Infektsii, 17(3), 57-61 (in Russian).

Vemula, V. N., Li, L., Thoon, K. C., Chong, C. Y., Tee, N. W. S., Maiwald, M., \& Tan, N. W. H. (2016). Risk factors and clinical profile of measles infection in children in Singapore. Infection, Disease and Health, 21(4), 192-196.

Verguet, S., Johri, M., Morris, S. K., Gauvreauf, C. L., Jha, P., \& Jit, M. (2015). Controlling measles using supplemental immunization activities: A mathematical model to inform optimal policy. Vaccine, 33(10), 1291-1296.

Volyanska, L. A., Burbela, E. I., \& Romanyuk, L. B. (2019). Nekontrol'ovanist' koru v epohu kerovanih infekcii [Uncontrolled measles in the age of controlled infections]. Zdorov'e Rebenka, 14(4), 242-249 (in Ukrainian).

Yevtushenko, V. V., Kramarov, S. O., Shadrin, V. O., Markov, A. I., Kaminsk, T. M \& Hrechukha, Y. O. (2019). Klinicheskie i epidemiologicheskie osobennosti kori u gospitalizirovannyh detej vo vremja dvuh vspyshek (2005-2006 i 2017 2018 gg.) v Ukraine [Clinical and epidemiological features of measles in children hospitalized during two outbreaks (2005-2006 and 2017-2018) in Ukraine]. Zaporozhskij Medicinskij Zhumal, 21, 808-814 (in Ukrainian).

Yunasova, T. N., Gorenkov, D. V., Rukavishnikov, A. V., Movsesyants, A. A., \& Merkulov, V. A. (2019). Analiz zabolevaemosti kor'ju v Rossii i problemy profilaktiki kori na etape eliminacii [Analysis of measles incidence in Russia and problems of measles prevention at the elimination stage]. Biopreparaty, Profilaktika, 19, 154-160 (in Russian).

Zeng, Y., Luo, M., Chen, J., He, H., Deng, X., Xie, S., \& Fang, Y. (2019). An economic evaluation of the current measles vaccination program: A case study in Zhejiang Province, east China. Vaccine, 37(23), 3071-3077.

Zhanga, R. O., Li, H. B., Li, F. Y., Han, L. H., \& Xiong, Y. M. (2017). Epidemiological characteristics of measles from 2000 to 2014: Results of a measles catch-up vaccination campaign in Xianyang, China. Journal of Infection and Public Health, 10(5), 624-629. 